\title{
COBALT-FREE, IRON-BASE CAST SUPERALLOYS
}

\author{
D. L. Sponseller \\ W. C. Hagel \\ Climax Molybdenum Company of Michigan, Ann Arbor, Michigan
}

The iron-base cast superalioys XF-818 and XF-527 are costsaving alternatives to certain cobalt-containing superalzoys. These geopolitically less sensitive new alzoys have low row materials cost, good castability in air, good machinability, and do not require heat-treatment. AZZoy XF-818 is intended for app Zications requiring good elevated-temperature strenglh arud oxidation resistance up to about $870 \mathrm{C}(1600 \mathrm{~F})$. Alloy XF-527 is intended for applications up to about $980 \mathrm{C}(1800 \mathrm{~F})$ that require moderately high elevated-temperature strength and good resistance to oxidation and/or hot comosion. Properties are presented and applications trials are discussed.

\section{INTRODUCTION}

Those concerned with cost reductions and energy and material conservation recognize that iron-base superalloys should be developed and promoted for certain applications now dominated by cobalt- and nickel-base alloys. Initial efforts were made about 25 years ago by the Chrysler Corporation and by Chryslersponsored researchers at the University of Michigan. Compositions and rupture strengths of the Chrysler CRM-6D, 15D, 17D and $18 \mathrm{D}$ alloys are listed in Ref. (1). These alloys sometimes experience extensive mold-metal reaction and require a prolonged aging heat treatment. An alloy developed in the program at the University of Michigan and containing Fe-18Cr-18Ni-5Mo-1.25B$0.3 \mathrm{C}$ had attractive rupture strength in the as-cast condition, being strengthened by eutectic borides and carbides (2). It has since been discovered at the Climax Laboratory that boron and carbon concentrations should be reduced to $0.7-0.9 \%$ and $0.08-$ $0.20 \%$, respectively, for better ductility. Depending on whether a proposed application requires higher strength or increased hot-corrosion resistance, two major alloy types were developed. These are known as XF-818 (Fe-7.5Mo-18Cr-18Ni-0.7B$0.4 \mathrm{Cb}-0.3 \mathrm{Si}-0.2 \mathrm{C}-0.15 \mathrm{Mn}-0.12 \mathrm{~N})$ and $\mathrm{XF}-527(\mathrm{Fe}-5 \mathrm{Mo}-27 \mathrm{Cr}-30 \mathrm{Ni}-$ $1.5 \mathrm{Si}-0.9 \mathrm{~B}-0.4 \mathrm{Mn}-0.12 \mathrm{~N}-0.08 \mathrm{C})$. This paper will review key properties of the two alloy types and will describe some of the heat-engine and die applications undergoing present consideration. 
EXPERTMENTAI PROCEDURES

The two principal alloys described in this paper are the most promising of many iron-base superalloys that were evaluated at the Climax Laboratory. Compositions of all heats tested, in \% are:

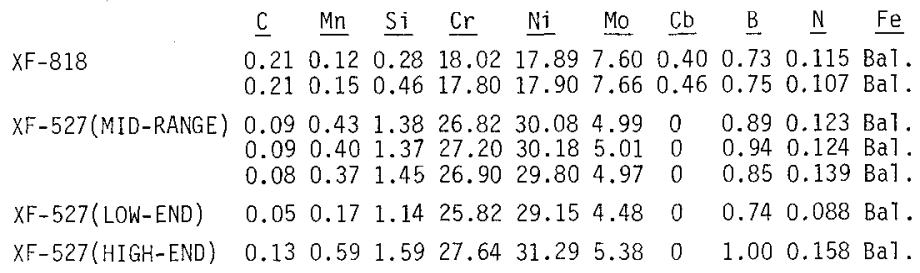

Heats weighing 25 or $60 \mathrm{~kg}$ (55 or $130 \mathrm{lb}$ ) were air-induction melted; threaded test bars were investment-cast and at least one Y-block was sand-cast for each alloy. Several processing variables were examined for XF-527: 1) composition, with one heat at the low end, three heats at mid-range, and one heat at the high end of the melting range; 2) solidification rate, with Y-blocks chill-cast in $13 \mathrm{~mm}$ (0.5 in.) steel molds and sand cast in a heavy section, $75 \mathrm{~mm}$ ( $3 \mathrm{in.)}$ mold; 3) welding, with full crosssection repair welds at mid-length of creep-rupture test bars. No heat treatment was used for XF-818 and XF-527 test materials. Appropriate specimens in the as-cast condition were evaluated for microstructure, phase identity, density, thermal expansion, impact strength, fracture toughness, hardness, tensile and creeprupture properties, oxidation and hot corrosion resistance. Heats of cobalt-base FSX-414 (Co-0.28C-0.22Mn-0.72Si-29.43Cr$10.58 \mathrm{Ni}-7.10 \mathrm{~W}-0.012 \mathrm{~B}-0.038 \mathrm{~N})$ and iron-base CRM-18D (Fe-0.78C$5.25 \mathrm{Mn}-0.58 \mathrm{Si}-23.41 \mathrm{Cr}-5.16 \mathrm{Ni}-5.08 \mathrm{Co}-1.96 \mathrm{Cb}-0.86 \mathrm{Mo}-0.83 \mathrm{~W}-0.012 \mathrm{~B}-$ $0.226 \mathrm{~N}$ ) were cast, given their standard heat treatments, and subjected to certain tests as reference alloys. Moreover, $13 \times 13 \mathrm{x}$ $75 \mathrm{~mm}(0.5 \times 0.5 \times 3$ in.) bars of six commercial superalloys were supplied by an investment-casting firm for use as reference alloys in oxidation and sulfidation tests. The effects of aging at 650-980 C (1200-1800 F) for 1000 hours on hardness, microstructure and tensile properties of $\mathrm{XF}-527$ were determined.

\section{RESULTS AND DISCUSSION}

\section{Characterization of As-Cast Material}

Microstructure. Austenite dendrites comprise the major constituent in both alloys, and dendrite arms are surrounded by boride- and carbide-containing eutectic constituents (Fig. 1). The dominant eutectic constituent in XF-818 (Fig. la) contains the (Mo, $\mathrm{Cr}$ ) boride $\mathrm{M}_{3} \mathrm{~B}_{2}$ interleaved with ductile austenite, giving creep resistance with a modest amount of room-temperature ductility. Such a combination of ductile and hard phases results only from boron, not carbon additions to alloys of the 


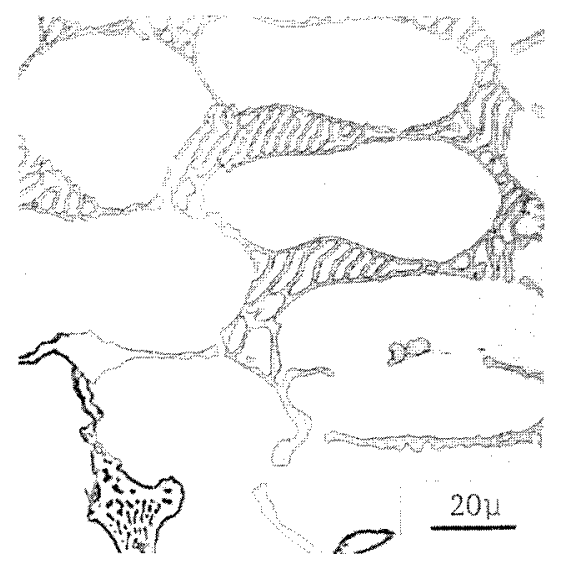

(A) $X F-818$

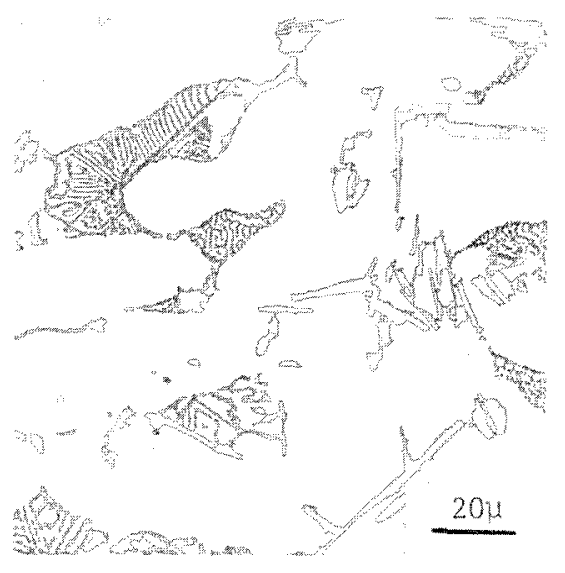

(B) $X F-527$

FIG. 1 MICROSTRUCTURES OF AS-CAST TENSILE TEST BARS OF XF-818 AND XF-527.

ETCHED ELECTROLYTICALLY WITH $50 \% \mathrm{HNO}_{3} ;$ X425

present type, Lhus explaining their high boron and low carbon contents. The presence of nominally $0.2 \% \mathrm{C}$ in $\mathrm{XF}-818$ gives rise to formation of a monolithic eutectic carbide, shown in the lower left portion of Fig. 1a. Alloy 527, (Fig. 1b), contains less of the lamellar eutectic and also contains large, irregularly shaped plates and rods identified as the ( $\mathrm{Cr}, \mathrm{Mo}$ ) boride $\mathrm{M}_{2} \mathrm{~B}$.

Physical Properties. Densities of the subject alloy are given in Table 1 . The values are comparable to those of most nickel-base superalloys, and nearly $10 \%$ lower than for cobaltbase superalloys. The thermal expansion coefficients of XF-818 and $\mathrm{XF}-527$ are moderately greater and just slightly greater, respectively, than for nickel- and cobalt-base superalloys.

Mechanical Properties at Room Temperature. Cast-to-size test bars of the subject alloys have hardness values of about HRC 20, Table 1. This low hardness, in combination with the chip-breaking effect of the eutectic constituents, makes the alloys readily machinable, although moderate tool wear is experienced.

As seen in Table 1, room-temperature yield and tensile strengths of investment-cast test bars, 1ike hardness, are relatively low. Of special interest, in view of the large volume fractions of eutectic constituents in these alloys, are their room-temperature elongations of over $1.5 \%$, as measured by electrical resistance strain gauges.

Tests of three unnotched Charpy impact specimens each at room temperature reveal mean impact energies of 8.9 and $8.2 \mathrm{~J}$ (6. 6 and $6.0 \mathrm{ft}-1 \mathrm{~b}$ ) for $\mathrm{XF}-818$ and $\mathrm{XF}-527$, respectively. Fracture toughness values, as determined on three compact tension 


\section{6 / Superalloys 1980}

TABLE I PHYSICAL AND MECHANICAL PROPERTIES

\begin{tabular}{|c|c|c|c|c|}
\hline PROPERTY & & $X F-818$ & & $X F-527$ \\
\hline DENSITY & 7.98 & $(0.288)$ & 7.86 & $(0.284)$ \\
\hline $\begin{array}{l}\text { LINEAR COEF. TH. EXP., } 10^{-6} /{ }^{\circ} \mathrm{C}\left({ }^{\circ} \mathrm{F}\right) \\
\text { RM. T. TO } 760 \mathrm{C}(1400 \mathrm{~F}) \\
\text { RM. T. TO } 980 \mathrm{C}(1800 \mathrm{~F})\end{array}$ & $\begin{array}{l}17.00 \\
17.37\end{array}$ & $\left(\begin{array}{l}9.44) \\
9.65)\end{array}\right.$ & $\begin{array}{l}15.94 \\
16.21\end{array}$ & $\left(\begin{array}{l}8.86) \\
9.01)\end{array}\right.$ \\
\hline HARDNESS, HRC & & 20 & & 19 \\
\hline $\begin{array}{l}\text { RM. TEMP. TENSILE HROPERTIES } \\
\text { O.2\% Y.S., MPa (ksi) } \\
\text { U.T.S. MPa (ksi) } \\
\text { ELONGATION, \& }\end{array}$ & $\begin{array}{l}411 \\
672\end{array}$ & $\begin{array}{c}\left(\begin{array}{l}59.6 \\
97.4\end{array}\right) \\
1.60\end{array}$ & $\begin{array}{l}394 \\
572\end{array}$ & $\begin{array}{r}(57.1) \\
(83.0) \\
1.71\end{array}$ \\
\hline $\begin{array}{l}\text { IMPACT TOUGIINESS, J (ft-1b) } \\
\text { (UNNOTCHED CHARPY) }\end{array}$ & 8.9 & $(6.6)$ & 8.2 & $(6.0)$ \\
\hline $\begin{array}{l}\text { FRACTURE TOUGHNESS, } \\
\mathrm{K}_{\mathrm{IC}}, \mathrm{MPa} \sqrt{\mathrm{m}}(\mathrm{kSi} \sqrt{\mathrm{in}} .)\end{array}$ & 44.7 & $(40.7)$ & 45.3 & $(41.2)$ \\
\hline $\begin{array}{l}\text { ELEV. TEMP. U.T.S., MPa (ksi); [\% [1.] } \\
650 \mathrm{C}(1200 \mathrm{~F}) \\
760 \mathrm{C}(1400 \mathrm{~F}) \\
870 \mathrm{C}(1600 \mathrm{~F}) \\
980 \mathrm{C}(1800 \mathrm{~F}) \\
1095 \mathrm{C}(2000 \mathrm{~F})\end{array}$ & $\begin{array}{c}629 \\
528 \\
334 \\
183 \\
-\end{array}$ & $\begin{array}{c}(91.2)[4.5] \\
(76.6)[5.0] \\
(48.4)[18.0] \\
(26.6)[16.0] \\
-\quad-\end{array}$ & $\begin{array}{r}527 \\
447 \\
308 \\
176 \\
83\end{array}$ & $\begin{array}{l}(76.4)[6.0] \\
(64.9)[7.5] \\
(44.6)[11.5] \\
(25.5)[23.5] \\
(12.0)[19.5]\end{array}$ \\
\hline
\end{tabular}

specimens per alloy, are 44.7 and $45.3 \mathrm{MPa} \sqrt{\mathrm{m}}(40.7$ and 41.2

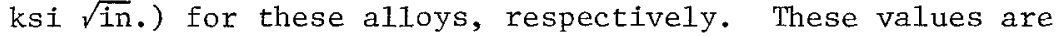
rather high for alloys with just over $1.5 \%$ elongation and are believed to reflect the presence of ductile austenite in eutectic constituents and the irregular fracture paths around dendrite arms.

Elevated-Temperature Tensile Strength. Alloy XF-818 surpasses XF-527 in tensile strength at $650 \mathrm{C}$ (1200 F), but the advantage tends to diminish at higher temperatures (Table 1 ). At $870 \mathrm{C}(1600 \mathrm{~F})$, the two alloys have tensile strengths of $334 \mathrm{MPa}$ $(48.4 \mathrm{ksi})$ and $308 \mathrm{MPa}(44.6 \mathrm{ksi})$, respectively, values that are unusually high for iron-base alloys and that rank high among those for all non- $\gamma^{\prime}$-strengthened superalloys. Elongations are significantly higher at $650 \mathrm{C}(1200 \mathrm{~F})$ than at room temperature and increase markedly with rising temperature.

Creep-Rupture Properties. The results of all creep-rupture tests performed on investment-cast test bars of XF-818 and "midrange" XF-527 are represented by the data points and curves of Fig. 2. These test results exhibit only minor scatter. Alloy $\mathrm{XF}-818$ is markedly superior in rupture strength to XF-527 at lower parameters but about half of the relative advantage is lost in going to the highest common testing parameters. Rupture elongations for $\mathrm{XF}-818$ increase from about 5 to $25 \%$ and those for XF-527 increase from about 5 to $40 \%$ with increasing parameter. Also shown in Fig. 2 is a shaded band for XF-527. Included within this band are test results for specimens representing the 


\section{L. Sponseller, W. C. Hagel / 77}
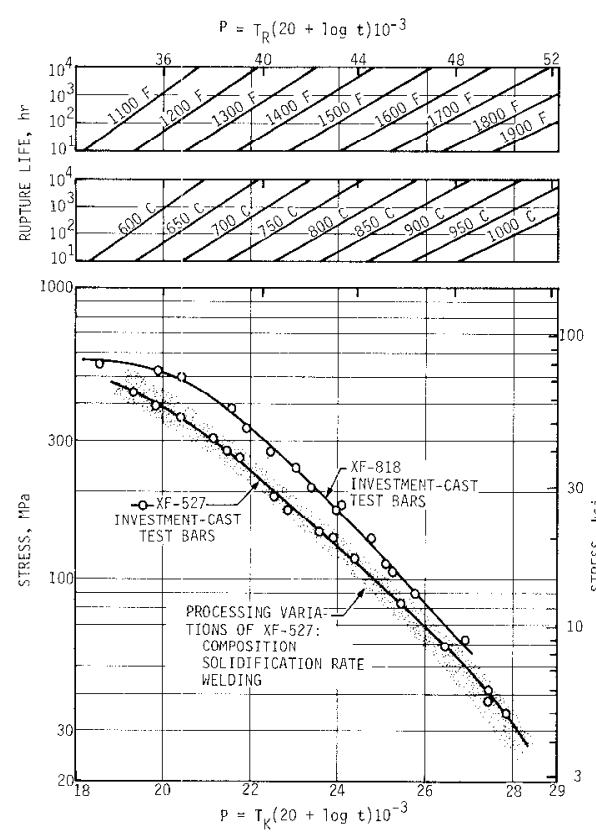

FIG. 2 LARSON-MILLER CURVE FOR XF-818 AND XF-527. THE RUPTURE POINTS FOR ALL PROCESSING VARIATIONS OF XF-527 LIE WITHIN IHE SHALLU BANU. processing variations described in "Experimental. Procedures." The results were as would be expected: "low-end" heats were at the bottom of the band and "high-end" heats at the top of the band; chill-cast specimens were represented by a steeper and heavy section specimens by a less steep Larson-Miller curve than for the investmentcast test bars. Also, points for welded specimens fel 1 almost exactly on their respective Larson-Miller curves. Because the band representing all processing variations of $\mathrm{XF}-527$ is relatively narrow, this alloy, and presumably XF818, should exhibit rather consistent rupture behavior when processed under a wide variety of conditions.

The present alloys are compared in Fig. 3 with some widely used commercial alloys on the basis of 100-hour rupture strength over a range of temperatures. At $650 \mathrm{C}(1200 \mathrm{~F})$ the rupture strength of XF-818 is comparable to the highest values shown for alloy $713 \mathrm{C}$ and cast Udimet -500 at higher temperatures. The XF818 curve lies between curves for the high strength cobalt-base alloy Mar-M509 and the hot-corrosion-resistant cobalt-base alloys FSX-414 and X-45. Moreover, XF-818 is several times as strong as both cast $\mathrm{HK}$ alloy and wrought AISI 316 stainless steel. $\Lambda$ s previously shown, XF-52.7 has lower rupture strength than XF818. Alloy XF-527 is about $18 \mathrm{MPa}$ (2.5 ksi) weaker than FSX-414 at al1 temperatures, but surpasses $X-45$ in 100-hour rupture strength at temperatures up to about $815 \mathrm{C}(1500 \mathrm{~F})$. A comparison of XF-818 with commercial alloys at a 100-hour rupture strength of $350 \mathrm{MPa}$ ( $50 \mathrm{ksi}$ ) shows that the $\gamma^{\prime}$-strengthened U500 and $713 \mathrm{C}$ have 90 and $125 \mathrm{C}$ (160 and $225 \mathrm{~F}$ ) advantages in operating capability, respectively, over XF-818. This suggests; the use of $X F-818$ in those applications not requiring the full temperature capabilities of the vacuum-melted nickel-base alloys, but for which those alloys have been used, for lack of a suitable iron-base replacement. 


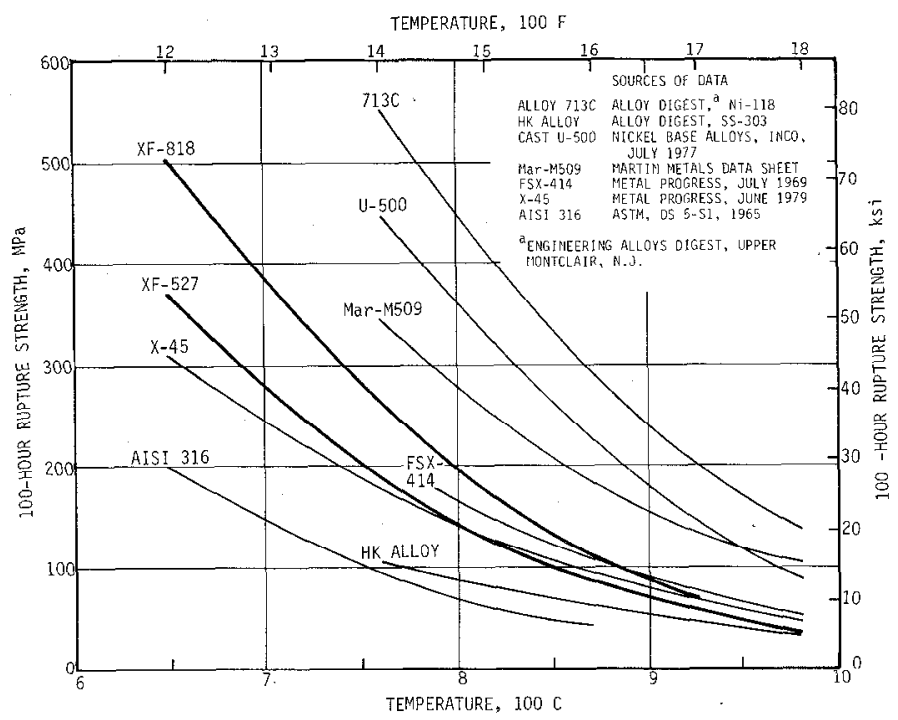

FIG.3 EFFECT OF TEMPERATJRE ON THE 100-HOUR RUPTURE STRENGTH OF XF-818 AND XF-527 AND OF SEVEN COMMERCIAL ALLOYS. ALL OF THE COMMERCIAL ALLOYS ARE CAST, EXCEPT AIS 1316.

\section{Ductility of Aged XF-527 and Reference Alloys}

Loss of ductility during service is a common problem in elevated-temperature alloys. The effect of aging for 1000 hours at $650,760,870$ and $980 \mathrm{C}(1200,1400,1600$ and $1800 \mathrm{~F})$ on room temperature ductility of XF-527 and two reference alloys is shown in Fig. 4. Represented in Fig. 4 are average data from duplicate investment-cast test bars of standard (mid-range) XF527 and its low-end and high-end compositional variations, and of FSX-414 and CRM-18D, and from specimens machined from the $13 \mathrm{~mm}$ (0.5 in.) chill-cast and the $75 \mathrm{~mm}$ ( 3 in.) sand-cast Yblocks of $\mathrm{XF}-527$. There is a progressive lowering of the curve for investment-cast XF-527 as composition increases from the low end to the high end of the range, owing mainly to the increased volume fraction of second phases. Aging causes at least a minor loss of ductility for all processing variations of XF527 at most temperatures. This is reflected in the moderate downward slope of the dashed curve in Fig. 4 that represents the average elongation for all XF-527 specimens. These losses, however, are far less drastic than the loss experienced by FSX-414 at 760 and $870 \mathrm{C}(1400$ and $1600 \mathrm{~F})$. A1though heat-treated FSX414 has $6.3 \%$ elongation before aging, the ductility after aging at $760 \mathrm{C}(1400 \mathrm{~F})$ drops sharply to $0.87 \%$, a value lower than for three of the five XF-527 processing conditions. At $870 \mathrm{C}$ $(1600 \mathrm{~F})$, FSX-414 is less seriously embrittled, but its $1.44 \%$ elongation is still below that for two of the XF-527 processing conditions. Marked loss of ductility by cast cobalt-base 


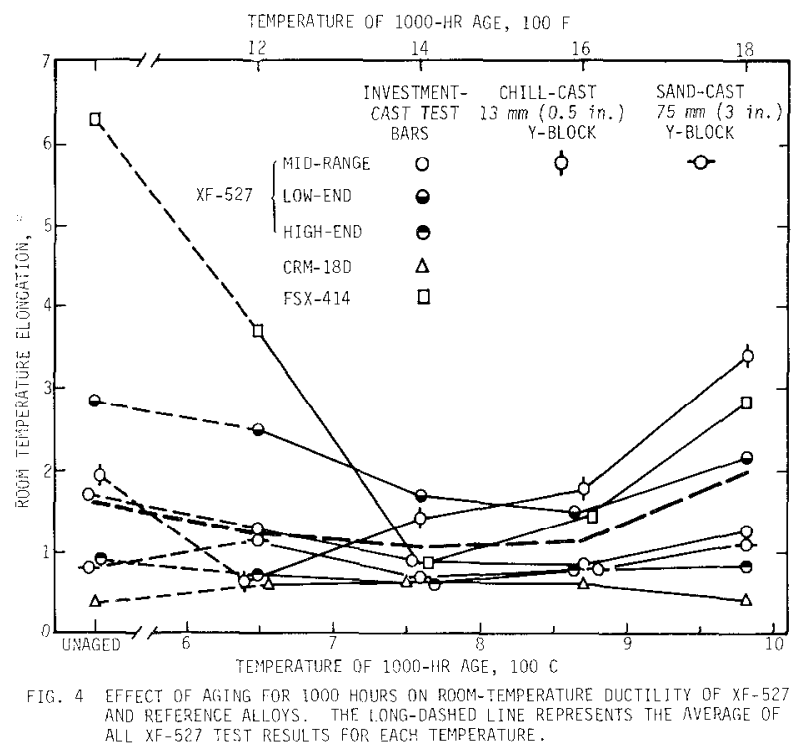

superalloys has been observed previously, and is attributed primarily to the profuse precipitation of fine $\mathrm{M}_{23} \mathrm{C}_{6}$ partticles in the matrix (3-6). Because XF-527 has low carbon content, it is not embrittled by carbide precipitation, a1though the alloy suffers mild loss of ductility from formation of some platelets at $760 \mathrm{C}(1400 \mathrm{~F})$. The profuse carbide precipitation occurring during the standard $650 \mathrm{C}$ $(1200 \mathrm{~F}) / 100$ hour heat treatment of CRM-18D causes low initial ductility in this alloy. Elongation values of this alloy after the 1000-hour aging treatments are somewhat higher, suggesting that the fine initial carbides have been overaged. In spite of this, the elongation values for aged CRM-18D are the lowest in this study.

\section{Surface Stability}

Alloy $\mathrm{XF}-818$ was designed primarily to have high rupture strength at moderate temperatures -- up to about $870 \mathrm{C}(1600 \mathrm{~F})$, and its oxidation resistance at this temperature is relatively high. Eecause the chromium content of this alloy is too low to afford hot corrosion resistance, XF-527 was subsequently developed for use in sulfur/salt-bearing atmospheres and for exposure in air at temperatures up to about $980 \mathrm{C}(1800 \mathrm{~F})$.

Oxidation Resistance. The weight gain of XF-818 after 500 hours in humidified air at $870 \mathrm{C}(1600 \mathrm{~F})$ is relatively low, $0.54 \mathrm{mg} / \mathrm{cm}^{2}$. After a 1000-hour exposure (ten 100-hour cycles) at $900 \mathrm{C}(1650 \mathrm{~F})$ in humidified air, $25 \times 10 \times 2.5 \mathrm{~mm}$ (1.0 x $0.4 \times 0.1$ in.) specimens of XF-527 and reference alloys experience the following weight gains $\left(\mathrm{mg} / \mathrm{cm}^{2}\right)$ : 


$\begin{array}{llll}\text { XF-527 } & 0.68 & \text { Mar-M509 } & 1.29 \\ \text { FSX-414 } & 0.88 & \text { Multimet (N-155) } & 1.39 \\ \text { CRM-18D } & 1.25 & \text { IN-738 } & 2.53 \\ \text { Alloy 713C } & 1.27 & \text { X-45 } & 3.14\end{array}$

This suggests that XF-527 would have adequate oxidation resistance for many applications.

Hot Corrosion Resistance. The same set of alloys described in the previous section was subjected to two hot corrosion tests. In the first test, coupons were coated with 1 $\mathrm{mg} / \mathrm{cm}^{2}$ of $70 \% \mathrm{Na}_{2} \mathrm{SO}_{4} / 30 \% \mathrm{NaCl}$ and exposed in humidified air at $900 \mathrm{C}(1650 \mathrm{~F})$ for 1000 hours. At 100-hour intervals, the specimens were cooled outside the furnace, weighed, and recoated as before. The results of this test (Fig. 5) show that alloy $713 \mathrm{C}$ corroded rapidly from the start, but that all other alloys had low initial attack. After 300 or 400 hours, six alloys, including "low-end" and "mid-range" XF-527, began suffering rather high weight gains under the influence of this high-chloride salt mixture. The "low-end" alloy was removed from test after 700 hours and the "mid-range" alloy was removed from test after 800 hours. The "high-end" alloy maintained exceptionally low weight gains through the first 900 hours of test but gained a substantial amount of weight in the final 100 hours of testing. Metallographic examination of the tested specimens revealed that $\mathrm{IN}-738$ and $\mathrm{X}-45$ suffered severe internal degradation during this test; grain boundaries throughout the specimens were attacked, rendering the test coupons weak and brittle.

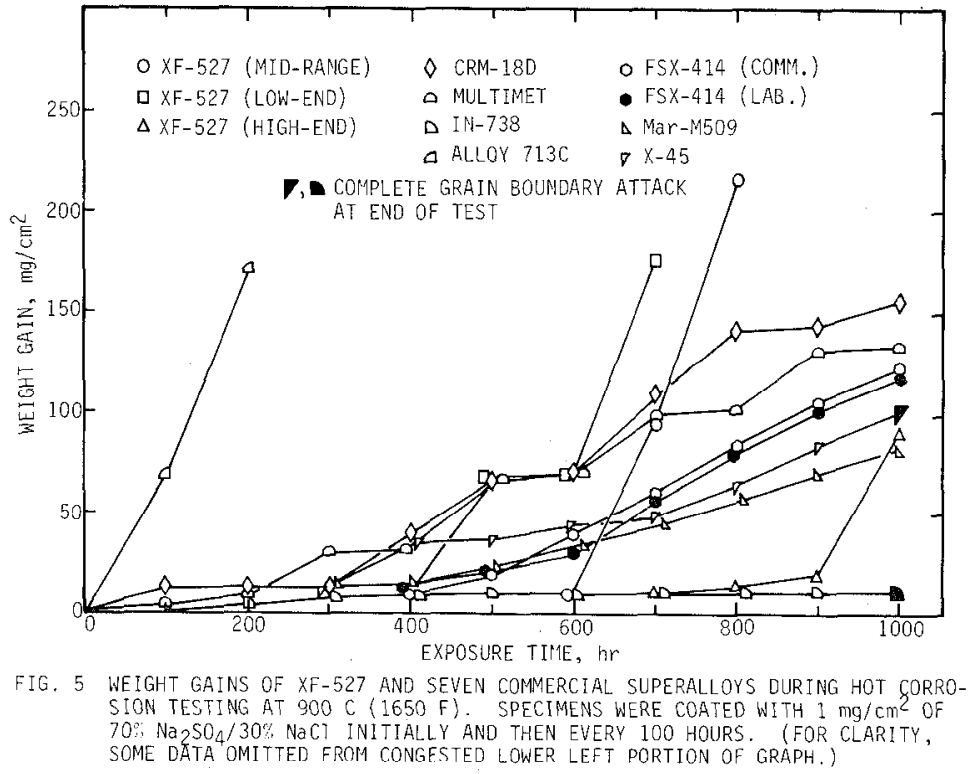




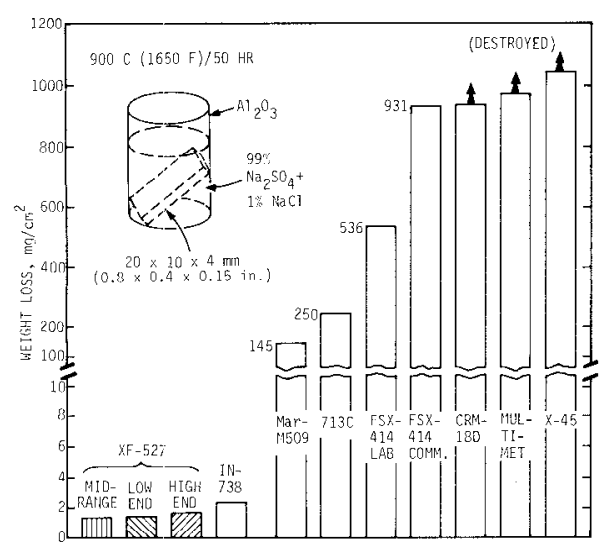

FIG. 6 WEIGHT LOSS OF XГ-527 AND SEYEN COMNERCIAL SUPF,RALLOYS AFTER 50-YIOUR CRLCIBLE. IPMERSIDFi TEST AT $900 \mathrm{C}(1650 \mathrm{~F}\}$
The second hot corrosion test was an immersion crucible test performed as described in Fig. 6 , the $99 \% \mathrm{Na}_{2} \mathrm{SO}_{4} / 1 \% \mathrm{NaCl}$ salt mixture being that used in earlier crucible tests by Graham et al. (7). As shown in Fig. 6, there was a very wide range of results. The three XF-527 specimens had low metal weight loss, and $\mathrm{IN}-738$ was nearly as good. Much greater losses were suffered by the other six alloys, three of the alloys -- CRM-18D, Multimet and $\mathrm{X}-45$-- having been total1y destroyed.

From these results it is evident that the surface stability of XF-527 is relatively good, but that some adjustment in composition may be necessary to assure satisfactory hot corrosion resistance If high-chlorfde environments are to be encountered.

\section{APPLICATIONS}

While evaluating the alloys as described in the preceding sections, some important processing advantages became apparent:

The alloys are cobalt-free and relatively inexpensive.

They can be melted and cast in air, and have high fluidity. Heat-treating is not required.

Machinability is markedly better than for other superalloys.

These advantages suggest the possibility of the cost-saving replacement of various alloys by the present alloys in certain applications. In general, the alloys most amenable to substitution are cast cobalt-containing X-40, X-45, FSX-414, and Multimet $(\mathrm{N}-155)$, because cobalt is a geopolitically sensitive and costly metal. In applications not requiring the full temperature capability of nickel-base alloys such as 713C, GMR-235, or cast U-500, replacement by XF-818 and possibly XF-527 may be considered.

Because of its good elevated-temperature strength, XF-818 has been evaluated for automotive exhaust valves. Two costsaving variations were cast into valves in shell molds and eva1uated by a U.S. automobile manufacturer. These alloys have significantly higher hot hardness and rupture strength (Fig. 7) than wrought $21-4 \mathrm{~N}$, an alloy widely used for exhaust valves. After passing preliminary fatigue tests, the valves were enginetested under the conditions shown in Table 2. The valves performed comparably to $21-4 \mathrm{~N}$, experiencing no significant amount 
of stretch or oxidation and no breakage under the repeated $1 \mathrm{~m}-$ pact loading to which exhaust valves are subjected. Nontechnical considerations have prevented these alloys from being tested further as of the present time. These alloys have attractive possibilities for exhaust valves, however, especially if rising operating temperatures of valves in clean-burning and fue1efficient engines should surpass the temperature capability of the present $21-4 \mathrm{~N}$ type of alloy. Economics may

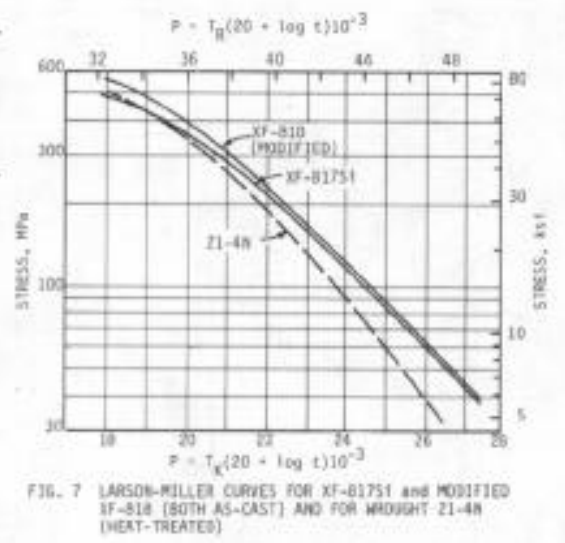

TABLE II CONDITIONS FOR TESTING XF-81B-TYPE EXHAUST VALVES IN V-8 ENGINES

\begin{tabular}{|c|c|c|c|}
\hline TYPE OF TEST & $\begin{array}{l}\text { W0. OF } \\
\text { ENGINES }\end{array}$ & TESTING CONDITIONS & LENGTH OF TESTS \\
\hline $\begin{array}{l}\text { DYRAMOMETER } \\
\text { DURABILITY TEST }\end{array}$ & 4 & $\begin{array}{l}\text { 75\% OF TIME AT PEAK POWER [4200- } \\
4400 \mathrm{RPM} ; \sim 200 \mathrm{~km} / \mathrm{h}(125 \mathrm{MPH}) 1 \\
25 \% \text { OF TIME AT PEAK TORQUE }\end{array}$ & 110-159 HOURS \\
\hline $\begin{array}{l}\text { VEHICLE } \\
\text { DURABILITY TEST }\end{array}$ & 3 & $\begin{array}{l}\text { NOPMAL DRIVING WITH FREQUENT } \\
\text { INTERVALS AT } \sim 160 \mathrm{~km} / \mathrm{h}(100 \mathrm{MPH}) \\
\text { INTERSPERSED }\end{array}$ & $\begin{array}{l}40,000-56,000 \mathrm{~km} \\
(25,000-35,000 \mathrm{miles})\end{array}$ \\
\hline
\end{tabular}

dictate that the high fluidity of the XF-818 type alloy be exploited, by die casting or permanent-mold casting the valves; feasibility of this has been explored with favorable results.

There is interest in using iron-base superalloys for small integral turbine wheels operating at moderate temperatures. Potential applications are automotive turbochargers and sma11 gas turbine engines that would serve as lightweight, lowemission propulsion units in snowmobiles, garden tractors, etc. A prototype turbine engine wheel made of an XF-818type alloy is shown in Fig. 8 . Tensile properties obtained on sub-sized specimens from the thick hub of this radialflow wheel (Table 3) compare rather favorably with those of a cast-to-size tensile specimen, showing the good

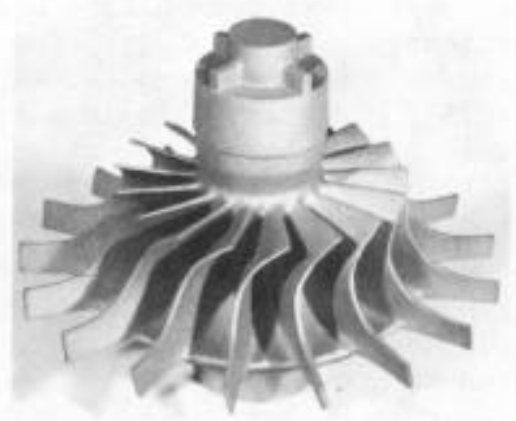

7I6. \& INTESRAL TURBINE WHEEL OF MODIFJED IF-818 THAT WAS PREPADED FOR ROOM TEMPERATURE SPIN IEST. THIS AADIAL FLOW WeEt DESTGN IS FOR A SNRLL. SIMGLE STAGE DEVELOWMENTAL GAS TURBiNE ENGINE. 
TABLE III TENSILE PROPERTIES OF SUB-SIZED TENSILE SPECIMENS MACHINED FROM XF-818-TYPE SMALL GAS TURBINE WHEEL

\begin{tabular}{|l|cc|c|c|}
\hline \multicolumn{1}{|c|}{$\begin{array}{c}\text { SPECIMEN } \\
\text { POSITION }\end{array}$} & $\begin{array}{c}\text { YIELD STRENGTH, } \\
\text { MPa } \\
\text { (ksi) }\end{array}$ & $\begin{array}{c}\text { ULTIMATE T.S. } \\
\text { MPa }(\mathrm{ks} i)\end{array}$ & $\begin{array}{c}\text { ELONG. } \\
\%\end{array}$ \\
\hline AXIAL & $433(62.8)$ & $570(82.7)$ & 2.3 \\
RADIAL & $437(62.5)$ & $618(89.6)$ & 2.9 \\
TRANSVERSE & $433(62.8)$ & $593(86.0)$ & 2.7 \\
CAST-TO-SIZE & $434(62.9)$ & $744(107.9)$ & 3.6 \\
\hline
\end{tabular}

castability of this alloy (8). During room-temperature spin tests of $115 \mathrm{~mm}$ ( $4.5 \mathrm{in.}$ ) diameter wheels, rotational speeds of 122,000 to $133,000 \mathrm{rpm}$ have been achieved before failure occurred (9). The subject wheels had been cast without any optimization of processing parameters. Significantly higher rotational velocities could probably be achieved by making minor changes in alloy composition and by studying the effects of casting conditions, and possibly of heat treatment.

Alloy $X F-527$ is under consideration as a nozzle-vane material for large industrial gas turbine engines. Typical nozzle vanes are pictured in the Westinghouse $W-501 \mathrm{D}$ vane segment of Fig. 9. This first trial casting of a vane segment from the present type of alloy was defect-free, thus demonstrating good castability. Alloy XF-527 has high resistance to scale formation in burner rig tests, but the mode of internal attack has yet to be identified. Minor alloy changes may be necessary.

The cast superalloy used thus far for cylinder heads and regenerator housings in the automotive Stirling-engine development program is cobalt-base $\mathrm{x}-40$. During the D.0.F. Contractors' Coordination Meeting of October 23-25, 1979, it was stated that materials testing will begin on replacing $X-40$ with $X F-818$. A rupture-strength advantage at operating temperatures and the weight saving that results from lower density add further justification beyond cost saving.

Isothermal or "hot-die" forging of titanium alloys permits forging of parts much closer to final dimensions than conventionally. Because of lower forging pressures, larger shapes can be forged with existing equipment. Isothermal forging of the low- $\beta$-transus alloy Ti-10V-2Fe-3A1 at $845 / 760 \mathrm{C}$ (1550/ $1400 \mathrm{~F}$ ) with dies of XF-818 appears feasible because the low material cost and good machinability

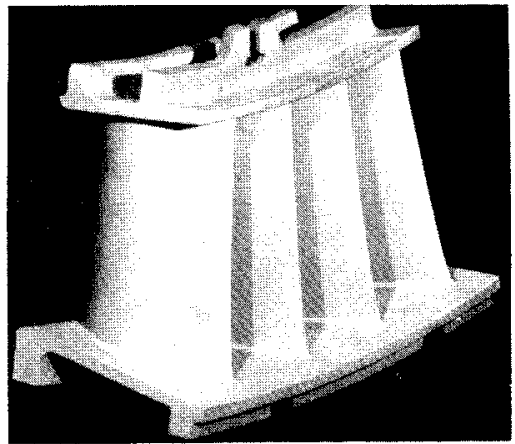

FIG. 9 TRIAL CASTING OF AN INDUSTRIAL GAS TURBINE VANE SEGMENT. THIS CASTING WEIGHS MORE THAN $36 \mathrm{~kg}(801 \mathrm{~b})$. 


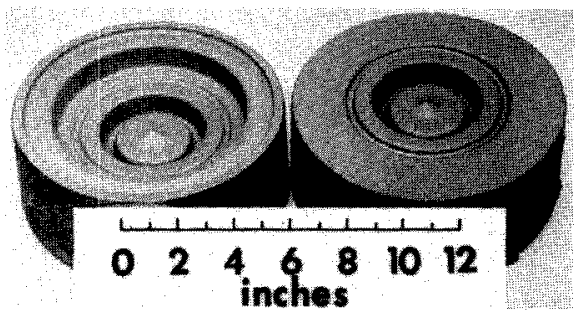

FIG. 10 CAST DIE SET OF XF-818 FOR THE ISOTHERMAL FORGING OF TITANIUM

of this alloy help to avoid high die costs. Such dies have been cast (Fig. 10). No die damage was observed after stressing this die set with a previously forged wheel of Rene 95 by squeezing 150 times at an average stress of 240-310 $\mathrm{MPa}$ (35-45 ksi) and a maximum die temperature of $815 \mathrm{C}$ (1500 F) (10). The die set was further tested by isothermally forging six wheels satisfactorily from titanium alloy bar stock, not from preforms. Further development of the isothermal forging of titanium alloys with XF-818 dies is under consideration. Other uses of XF-818 or XF-527 may also be considered.

\section{SUMMARY}

Two cobalt-free, ilron-base cast superalloys possessing attractive strength at elevated temperatues have been described. Because of low raw materials costs, excellent castability in air, good machinability, and the ability to be used in the as-cast condition, the alloys offer a significant cost-saving potential over other superalloys, especially those containing cobalt. Alioy $\mathrm{XF}-818$ is intended for service at temperatures up to about $870 \mathrm{C}$ $(1600 \mathrm{~F})$ in applications requiring good elevated-temperature strength and oxidation resistance. Alloy XF-527 is intended for service at temperatures up to about $980 \mathrm{C}(1800 \mathrm{~F})$ in applications where good hot corrosion resistance and moderately high elevated-temperature strength are required. Although these alloys may be suitable for certain applications without modification, some optimization of composition and/or processing may be advantageous for other applications, depending on service conditions.

\section{REFERENCES}

1. METAL PROGRESS DATABOOK, ASM, MID-JUNE 1979, pp. 102-103.

2. D. L. SPONSELLER, R. W. KRAFT AND R. A. FLINN: "ADDITIVE EFFECTS OF ALLOYING ELEMENTS ON THE MECHANICAL PROPERTIES OF CAST AUSTENITIC ALLOYS AT $1500 \mathrm{~F}, "$ ASM TRANS. VOL. 54, NO.3,

1961 , pp. $526-538$.
3. N. J. GRANT, "THE STRESS RUPTURE AND CREEP PROPERTIES OF HEAT RESISTANT GAS TURBINE ALLIOYS," ASM TRANS., 39, 1947, P. 281.

4. C. P. SULLIVAN, M. J. DONACHIE, JR., AND F. R. MORRAL, COBALT-BASE SUPERALLOYS-1970, CENTRE D'INFORMATION DU COBALT, BURSSELS, $1970, \mathrm{pp}$. 14-16.

5. C. T. SIMS AND W. C. HAGEL, THE SUPERALLOYS, JOHN WILEY AND SONS, NEW YORK, 1972, p. 154

G. A. M. BCLTRAN, C. T. SI'TS AND N. T. WAGENHEIM, "THE HIGH-TFMPERATURE PROPERTIES OF MarM509," J. OF METALS, VOL. 22, N0. 9, 1969, p. 39.

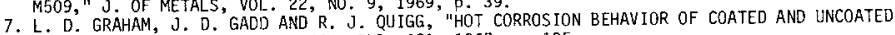
SUPERALLOYS," ASTM SPECIAL TECH. PUB. 421, 1967, p. 105.

SUPERALLOYS," ASTM SPECIAL TECH. PUB. 421, 1967, P. 105.
8. PERSONAL COMMUNICATION FROM W. E. GURWELL OF EATON CORP. TO D. L. SPONSELLER, 1975.
9. PERSONAL COMMUNICATION FROM R. CHUTE OF EATON CORP. TO D. L. SPONSELLER, 1980.

9. PERSONAL COMMUNICATION FRONAL COMMUNICATION FROM W. F. COUTS OF THE WYMAN-GORDON CO. TO D. L. SPONSELLER, 1980. 